\title{
Salicylate-Independent Lesion Formation in Arabidopsis Isd Mutants
}

\author{
Michelle D. Hunt, ${ }^{1}$ Terrence P. Delaney, ${ }^{1}$ Robert A. Dietrich, ${ }^{2}$ Kris B. Weymann, ${ }^{1}$ Jeffery L. Dangl, ${ }^{2}$ and \\ John A. Ryals ${ }^{1}$ \\ ${ }^{1}$ Biotechnology and Genomics Center, Novartis Crop Protection, Inc., P.O. Box 12257, Research Triangle \\ Park, NC 27709 U.S.A.; ${ }^{2}$ University of North Carolina, Department of Biology, 108 Coker Hall, Chapel Hill \\ 27514 U.S.A. \\ Received 13 February 1997. Accepted 25 February 1997.
}

In many interactions of plants with pathogens, the primary host defense reaction is accompanied by plant cell death at the site of infection. The resulting lesions are correlated with the establishment of an inducible resistance in plants called systemic acquired resistance (SAR), for which salicylic acid (SA) accumulation is a critical signaling event in Arabidopsis and tobacco. In Arabidopsis, the lesions simulating disease $(l s d)$ mutants spontaneously develop lesions in the absence of pathogen infection. Furthermore, lsd mutants express SAR marker genes when lesions are present and are resistant to the same spectrum of pathogens as plants activated for SAR by necrogenic pathogen infection. To assess the epistatic relationship between SA accumulation and cell death, transgenic Arabidopsis unable to accumulate $\mathrm{SA}$ due to the expression of the salicylate hydroxylase (nahG) gene were used in crosses with the dominant mutants $l s d 2$ or $l s d 4$. Progeny from the crosses were inhibited for SAR gene expression and disease resistance. However, these progeny retained the spontaneous cell death phenotype similar to siblings not expressing nahG. Because lesions form in the absence of SA accumulation for $l s d 2$ and $l s d 4$, a model is suggested in which lesion formation in these two mutants is determined prior to SA accumulation in SAR signal transduction. By contrast, the loss of SAR gene expression and disease resistance in $n a h G$-expressing $l s d$ mutants indicates that these traits are dependent upon $\mathrm{SA}$ accumulation in the SAR signal transduction pathway.

Additional keywords: autofluorescence, callose, feedback amplification loop, Peronospora parasitica isolate Noco, PR gene expression.

The correlation between rapid, hypersensitive cell death and plant disease resistance responses has been widely described (Klement 1982; Keen 1982; Keen and Staskawicz 1988). Pathogen-associated cell death is also known to activate an inducible, systemic, broad-spectrum resistance called systemic acquired resistance (SAR; for reviews see Ross 1961; Kuc

Corresponding author: John A. Ryals; Fax: +1 919541 8557;

E-mail: ryalsj@a1.abru.cg.com

Present address of Terrence P. Delaney: Cornell University, Department of Plant Pathology, 341 Plant Science Building, Ithaca, NY 14853-4203 U.S.A.
1982; Ryals et al. 1994; Chen et al. 1995; Neuenschwander et al. 1996; Hunt and Ryals 1996; Shirasu et al. 1996; Ryals et al. 1996). SAR is correlated with the expression of marker genes and an increase in salicylic acid (SA) levels in both infected and noninfected leaves (Uknes et al. 1992, 1993b). Expression of a bacterial salicylate hydroxylase (nahG) transgene in Arabidopsis and tobacco inhibits SA accumulation in response to pathogen infection and prevents not only the establishment of SAR (Gaffney et al. 1993; Lawton et al. 1995) but gene-for-gene resistance as well (Delaney et al. 1994).

Necrogenic pathogen infection is required for the biological activation of SAR. However, certain mutations can lead to pathogen-independent activation of the SAR pathway. For example, Arabidopsis lesions simulating disease $(l s d)$ and accelerated cell death $(a c d 2)$ mutants that form spontaneous lesions exhibit histochemical markers associated with defense-related cell death, show elevated SAR gene expression, and exhibit heightened disease resistance (Dietrich et al. 1994; Greenberg et al. 1994; Weymann et al. 1995). Similar lesioned phenotypes exist in other plant species, including maize (Walbot et al. 1983), barley (Wolter et al. 1993), and tomato (Langford 1948), with the latter two also displaying enhanced disease resistance. A correlation between spontaneous cell death and disease resistance is also evident in transgenic tobacco expressing a bacterial proton pump (Mittler et al. 1995), the A1 subunit of cholera toxin (Beffa et al. 1995), or a ubiquitin variant (Becker et al. 1993). Collectively, these data indicate that many types of cellular perturbation can trigger cell death, and some simultaneously trigger SAR. Because of the similarities between mutant and pathogen-activated SAR in plants, we have utilized $l s d$ mutants as a model to explore the epistatic relationship between cell death, SA accumulation, and the induction of SAR genes and resistance. Here we describe results obtained from inhibiting SA accumulation in $l s d 2$ and $l s d 4$ plants by $n a h G$ expression and discuss the implications of these results regarding cell death and SAR signal transduction.

\section{RESULTS}

Lesion formation in $l s d$ mutants expressing $n a h G$.

The dominant mutants $l s d 2$ and $l s d 4$ (Dietrich et al. 1994) were used as pollen donors in crosses to transgenic plants expressing salicylate hydroxylase ( $n a h G$; Gaffney et al. 1993; Lawton et al. 1995). Lesioned $\mathrm{F}_{2}$ and $\mathrm{F}_{3}$ progeny were evaluated for the expression of $n a h G$ by RNA blot analysis with a 
$n a h G$ probe. Figure 1 presents $l s d 2$ and $l s d 4$ progeny that either contain or lack $n a h G$. Lesion morphology in $l s d 2$ is not altered by the expression of $n a h G$. However, $n a h G$-containing $l s d 4$ plants exhibit lesions that are more severe than the lesions exhibited by $l s d 4$ plants lacking the transgene.

Lesion histology in $l s d 2$ and $l s d 4$ mutants expressing $n a h G$.

The accumulation of autofluorescent phenolic compounds and deposition of callose are markers associated with lesion formation in response to pathogen invasion (Koga et al. 1980) and lesions associated with $l s d 2$ and $l s d 4$ mutations (Dietrich et al. 1994). To assess the role of SA in lesion formation, we examined $l s d 2$ and $l s d 4$ progeny that expressed or lacked $n a h G$ for both the accumulation of autofluorescent material and the deposition of callose. Figure 2 shows micrographs of cross sections through leaf lesions examined by differential interference contrast (DIC) microscopy (column 1: A, D, G, J), ultraviolet light-stimulated autofluorescence (column 2: B, $\mathrm{E}, \mathrm{H}, \mathrm{K})$, and callose deposition visualized by fluorescence following aniline blue staining (column 3: C, F, I, L). Callose deposition and autofluorescent material accumulation in lesions of $l s d 2$ plants lacking or expressing $n a h G$ are similar. However, $l s d 4$ plants expressing $n a h G$ contain more callose and autofluorescent material throughout the leaf mesophyll, whereas deposition of these materials is confined to the lower mesophyll in $l s d 4$ plants lacking $n a h G$. Therefore, the more severely lesioned phenotype evident in $l s d 4$ plants expressing $n a h G$ is reflected at the histological level.

\section{PR gene expression in $l s d 2$ and $l s d 4$ mutants expressing $n a h G$.}

Expression of the SAR-associated pathogenesis-related (PR) genes PR-1, PR-2, and PR-5 was assessed in $l s d 2$ and $l s d 4$ progeny segregating for $n a h G$. Expression of these markers has previously been shown to correlate with the establishment of SAR in Arabidopsis in response to both biological and chemical SAR activators (Uknes et al. 1993a, 1993b; Lawton et al. 1996). A total of $57 \mathrm{~F}_{3} l s d 2$ progeny and $60 \mathrm{~F}_{2}$ $l s d 4$ progeny were evaluated for $n a h G$ expression. Figure 3 shows PR gene expression in a representative subset of four $l s d 2$ or $l s d 4$ progeny that either contain (+) or lack (-) nahG. High-level PR-1 expression in $l s d 2$ and $l s d 4$ is substantially reduced by expression of $n a h G$. While PR-2 and PR-5 expression is not as tightly correlated as that of PR-1 with SA accumulation, PR-2 and PR-5 also accumulate to substantially lower levels in $l s d$ mutants expressing $n a h G$.

\section{Reduction of SA accumulation results in disease susceptibility.}

Previously, Dietrich et al. (1994) demonstrated that lesionpositive $l s d 2$ and $l s d 4$ mutants were significantly resistant to isolates of Peronospora parasitica fully virulent on wild-type parental accessions. To assess the effect of inhibiting SA ac-

\section{Isd2}
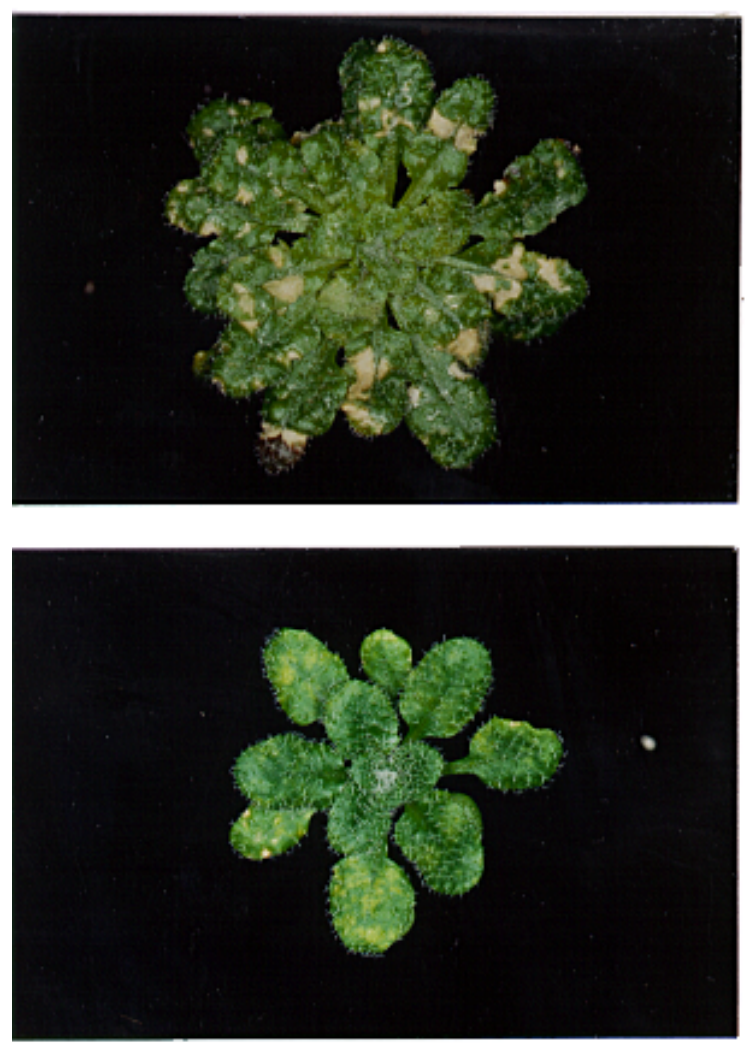

Isd4

\section{Isd2 x NahG}
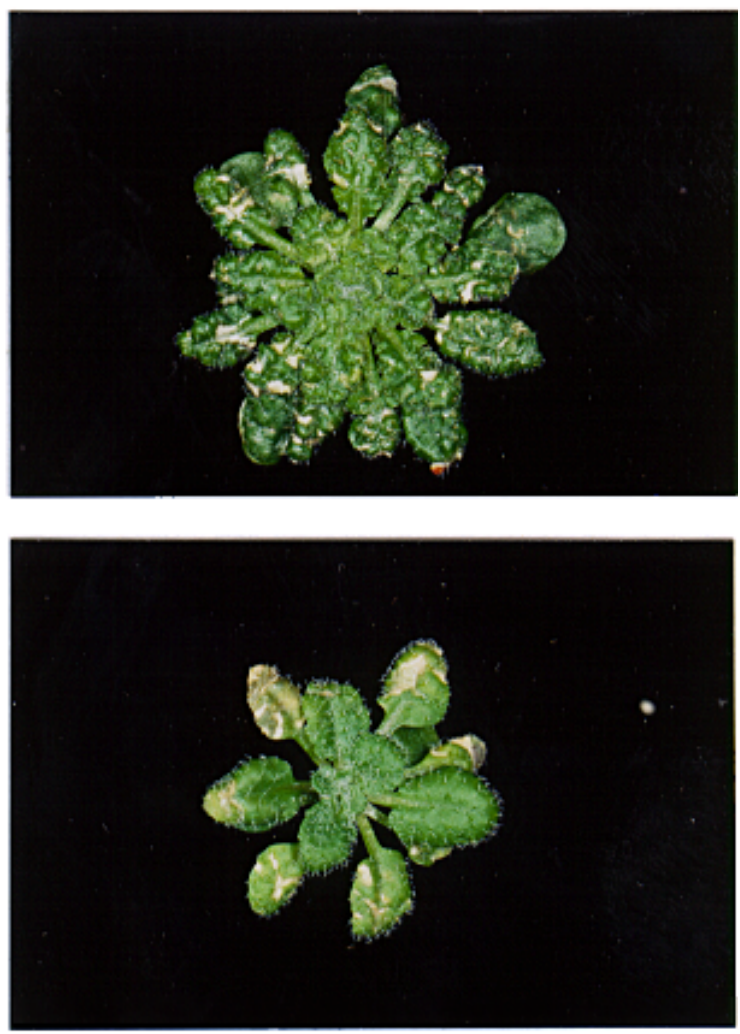

Isd4 x NahG

Fig. 1. Visible phenotype of $l s d / \mathrm{NahG}$ plants. Plant designations are located below and above each panel. 
cumulation on the disease-resistant phenotype of $l s d$ mutants, we tested $l s d 2 / \mathrm{NahG}$ plants by inoculation with the Noco isolate of $P$. parasitica. This fungal isolate is virulent on Arabidopsis ecotype Col-0, the parental accession for both $l s d 2$ and $\mathrm{NahG}$ lines. In $\mathrm{F}_{3}$ populations from this cross, lesioned individuals were identified, a leaf sample was harvested for RNA blot analysis to identify $n a h G$-expressing individuals (data not shown), and plants were inoculated with $P$. parasitica. Seven days after infection, plants were evaluated for severity of downy mildew disease. Table 1 shows that $l s d 2$ plants expressing $n a h G$ developed more severe disease symptoms than $l s d 2$ plants without $n a h G$. A representative comparison between $l s d 2$ plants expressing or lacking $n a h G$ is presented in Figure 4 . Because $l s d 4$ is in the Ws- 0 ecotype while $n a h G$ was transformed into Col-0, similar tests of pathogen resistance in $l s d 4 / \mathrm{NahG}$ plants were not possible because fungal isolates virulent on both parental accessions were not available.

\section{DISCUSSION}

In this manuscript, we show that $l s d 2$ and $l s d 4$ mutants unable to accumulate SA due to $n a h G$ expression show reduced
SAR gene expression and $l s d 2$ possesses a diminished disease resistance phenotype. However, development of lesions persists in the $n a h G$-expressing $l s d 2$ and $l s d 4$ mutants. Interestingly, the lesioned phenotype of $l s d 4 / \mathrm{NahG}$ progeny is more severe than in siblings lacking $n a h G$. The increased amount of callose and autofluorescent material in $l s d 4 / \mathrm{NahG}$ lesions is consistent with the more severe lesion morphology observed macroscopically. This correlates well with the observation that more severe lesions are evident in NahG tobacco and Arabidopsis plants infected with pathogens (Delaney et al. 1994; Ryals et al. 1995).

Our data indicate that the cell death triggered in $l s d 2$ and $l s d 4$ mutants is determined prior to the requirement for SAdependent processes during the onset of SAR signaling. Additional support for this proposal comes from two previous observations. First, induction of SAR with physiologically effective concentrations of SA or with the synthetic activating chemicals 2,6-dichloroisonicotinic acid (INA; Vernooij et al. 1995) or benzo(1,2,3)thiadiazole-7-carbothioic acid $S$-methyl ester (BTH; Friedrich et al. 1996; Lawton et al. 1996; Görlach et al. 1996) does not cause lesions to form in wild-type plants. Second, Arabidopsis mutants exist that accumulate SA and display con-
DIC
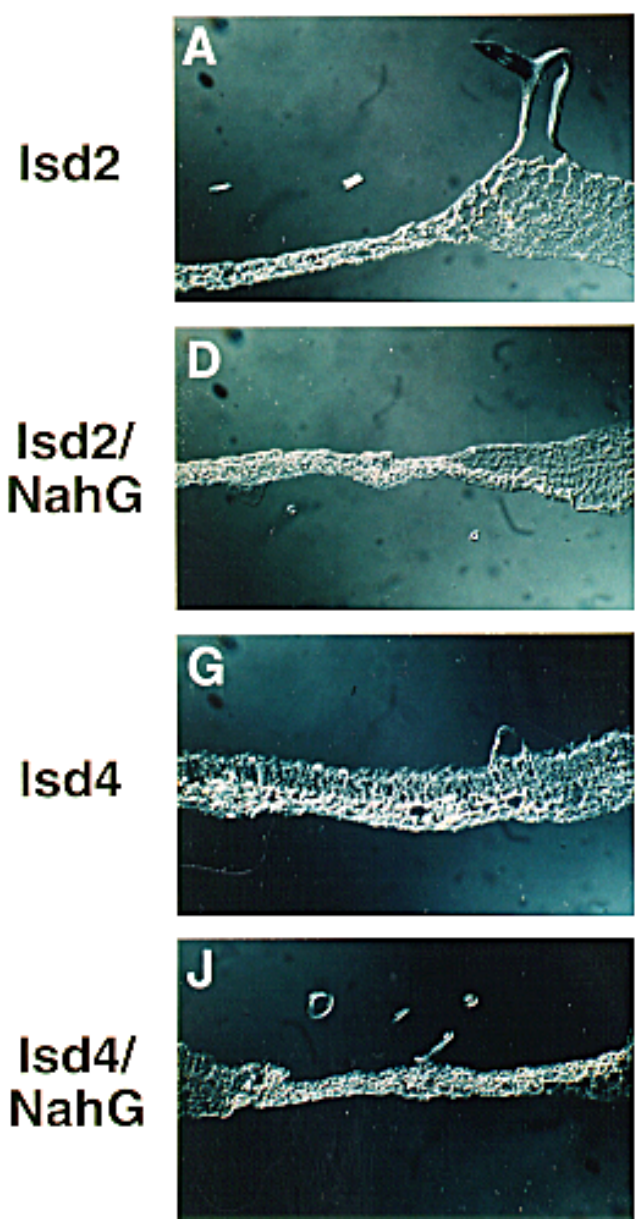

Autofluorescence
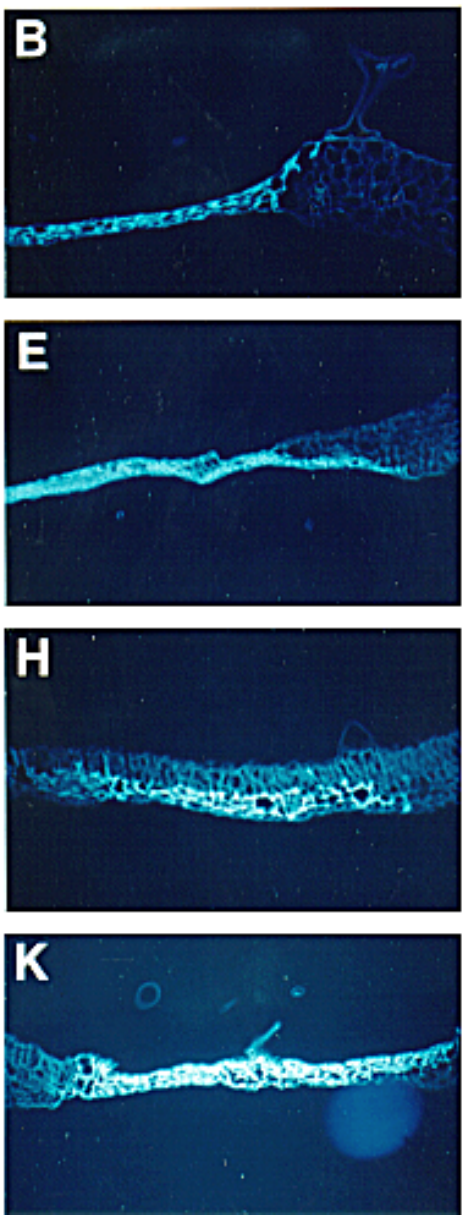

Callose
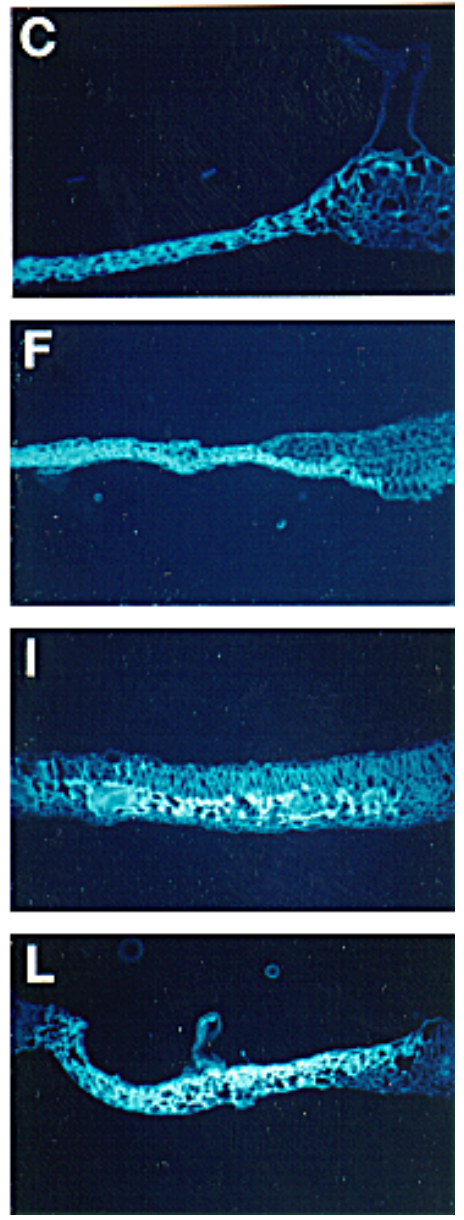

Fig. 2. Histology of lesions. Horizontal rows display leaf morphology from lesions of $l s d 2$ (A-C), $l s d 2 / \mathrm{NahG}$ (D-F), $l s d 4$ (G-I), and $l s d 4 / \mathrm{NahG}$ (J-L). Differential interference contrast images are shown in column one (A, D, G, J), ultraviolet light-stimulated autofluorescence in column two $(\mathbf{B}, \mathbf{E}, \mathbf{H}$, $\mathbf{K})$, and secondary fluorescence of callose following aniline blue staining in column three (C, F, I, L). 
stitutive activation of SAR but are distinguished from the $l s d$ and $\operatorname{acd} 2$ mutants by their absence of lesions (Bowling et al. 1994; H.-Y. Steiner, S. Uknes, K. Weymann, D. Chandler, S. Potter, E. Ward, and J. Ryals, unpublished data). Together, these data indicate that SA accumulation is not sufficient to cause lesion formation, consistent with a view that lesion formation can be determined prior to SA-dependent processes.

In contrast to the SA-independent lesion development exhibited by $l s d 2$ and $l s d 4$, SA accumulation is required for lesion formation in two additional mutants, $l s d 6$ and $l s d 7$ (Weymann et al. 1995). This contradiction indicates that cell death can cause or require SA accumulation, depending upon the nature of the mutation analyzed. These observations are consistent with the existence of a feedback amplification loop that is activated by SA or SA-dependent processes and can modify the initiation of cell death (Jones and Dangl 1996; Hunt and Ryals 1996; Ryals et al. 1996; Dangl et al. 1996). It appears that lesion formation occurs by at least two broadly defined mechanisms: those that are SA-independent and can stimulate SA-requiring processes ( $l s d 2$ and $l s d 4)$ and those that may require feedback amplification or SA-dependent potentiation of signaling events leading to cell death ( $l s d 6 / l s d 7$

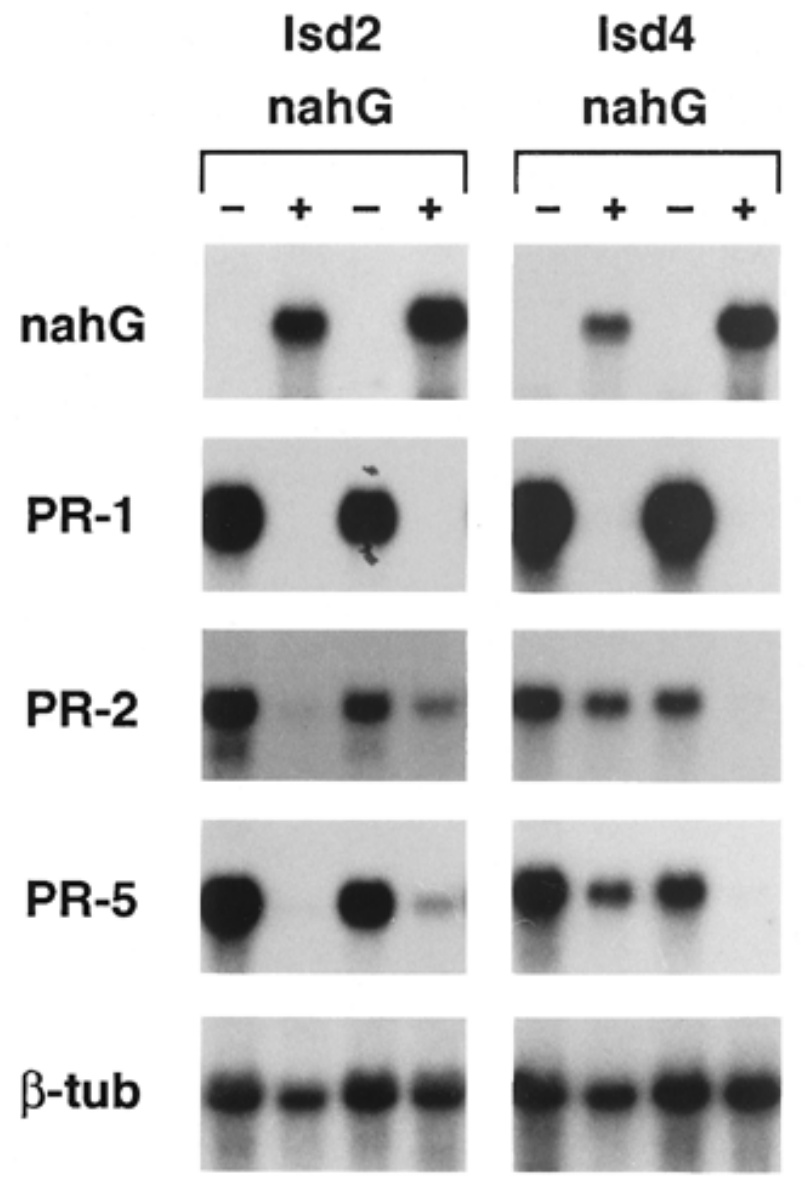

Fig. 3. Systemic acquired resistance (SAR) gene expression in $l s d / \mathrm{NahG}$ plants. Total RNA was extracted from $l s d 2$ and $l s d 4$ lesion-positive progeny that either contained (+) or lacked (-) nahG expression. Markers for SAR (PR-1, PR-2, and PR-5) and $n a h G$ status were used as probes. A $\beta$-tubulin probe was used to evaluate RNA loading.
[Weymann et al. 1995] and $l s d l$ [U. Neuenschwander, R. A. Dietrich, J. L. Dangl, and J. A. Ryals, unpublished results]).

Further support for a feedback loop in the SAR pathway can be found from recent results in tobacco (Mur et al. 1996) or cucumber (Fauth et al. 1996). In tobacco, treatment with SA prior to wounding or pathogen infection enhances or "potentiates" the expression of defense gene promoter fusions. Similarly, wounded cucumber seedlings treated with either SA or INA showed an enhanced rate of $\mathrm{H}_{2} \mathrm{O}_{2}$ production in response to fungal elicitors. Thus, in both cases early resistance or defense-related responses were conditioned by the activation of downstream components consistent with the existence of a feedback loop in the SAR pathway.

Pathogen-induced lesion formation has often been associated with the presence of defined histological markers (Koga et al. 1988). The deposition of autofluorescent phenolic compounds is one such marker (Mayama and Shishiyama 1976; Koga et al. 1980), as is callose deposition around sites of pathogen-induced lesion formation (Aist and Israel 1977; Görg et al. 1993). Lesion formation in $l s d$ mutants leading to disease resistance was also accompanied by accumulation of these histological markers (Dietrich et al. 1994). However, deposition of autofluorescent compounds and callose may not be specific for pathogen-associated cell death leading to SAR. Callose deposition has been documented to result from mechanical injury (Eschrich 1975), bruising (Dekayos 1972), injection of inorganic chemicals (Tighe and Heath 1982), thigmomorphogenesis (Jaffe et al. 1985), and the application of exogenous elements such as copper (Prokipcak and Ormrod 1986). Activation of SAR in response to these treatments has not been fully assessed, but SAR is not activated by mechanical wounding or stress (K. Lawton and S. Potter, unpublished results; Bozarth 1962). Lesion formation in response to the application of certain herbicides is also accompanied by the deposition of callose and autofluorescent material. However, there is not a consistent correlation with SAR gene expression and resistance (M. D. Hunt and J. A. Ryals, unpublished data; A. Molina, E. Ward, and J. A. Ryals, unpublished data). Taken together, these observations indicate that SAR signal transduction is not associated with all cell death events, even those that histochemically resemble pathogen-associated lesions, further illustrating the significance of the loci defined by the $l s d$ mutants in dissecting these processes.

PR-1 gene expression in $l s d 2$ and $l s d 4$ expressing $n a h G$ was inhibited; however, PR-2 and PR-5 displayed variable expression in different progeny, exhibiting some degree of SA-

Table 1. Disease rating of $l s d 2$ and $l s d 2 / \mathrm{NahG}$ progeny following infection with Peronospora parasitica ${ }^{\mathrm{a}}$

\begin{tabular}{|c|c|c|c|c|c|c|c|}
\hline \multirow[b]{2}{*}{ Plants } & \multicolumn{7}{|c|}{ Plants expressing disease levels (no.) ${ }^{b}$} \\
\hline & $\mathbf{0}$ & + & ++ & +++ & ++++ & +++++ & $\begin{array}{c}\text { Total } \\
\text { plants }\end{array}$ \\
\hline$l s d 2$ & 12 & 2 & 2 & 1 & 0 & 0 & 17 \\
\hline$d 2 / \mathrm{NahG}$ & 0 & 6 & 12 & 9 & 15 & 41 & 83 \\
\hline \multicolumn{8}{|c|}{$\begin{array}{l}\text { a } l s d 2 \text { and } l s d 2 / \mathrm{NahG} \text { progeny were inoculated with a suspension of } P \text {. } \\
\text { parasitica isolate Noco conidiospores }\left(1 \times 10^{5} \text { spores per ml) and rated }\right. \\
\text { for disease in individual plants after } 10 \text { days. } \\
\text { b Scale: } 0=\text { no conidiophores on plant; }+=\text { one leaf with } 1 \text { to } 15 \text { con- } \\
\text { idiophores; }++=\text { two leaves with } 1 \text { to } 15 \text { conidiophores; }+++=\text { one } \\
\text { leaf with } 15 \text { or more conidiophores; }++++=\text { two leaves with } 15 \text { or } \\
\text { more conidiophores; }+++++=\text { more than two leaves with } 15 \text { or more } \\
\text { conidiophores. }\end{array}$} \\
\hline
\end{tabular}


independence. Variable basal and stress-induced expression of PR-2 and PR-5 has been previously documented in Arabidopsis (Uknes et al. 1992; Mauch-Mani and Slusarenko 1994). In tobacco, PR-5 expression is elevated in response to methyl jasmonate and ethylene treatment (Xu et al. 1994). Such variability may indicate that PR-2 and PR-5 expression is also induced through signal transduction events effected by various stimuli but not necessarily leading to SAR. Therefore, we conclude that PR-2 and PR-5 mRNA accumulation in Arabidopsis is not tightly correlated with SAR activation.

The results presented in this study demonstrate that the cell death controls perturbed in $l s d 2$ and $l s d 4$ mutants can trigger SAR but do not depend upon SA for the formation of lesions. By contrast, SAR gene expression and resistance in these mutants depend upon SA accumulation. Identification of the genes affected in these mutants and further genetic dissection of the SAR signal transduction pathway will allow more refined understanding of pathways that control cell death and activate SAR.

\section{MATERIALS AND METHODS}

\section{Crosses with NahG Arabidopsis.}

NahG Arabidopsis was generated as described in Delaney et al. (1994). $l s d 2$ and $l s d 4$ were isolated as described in Dietrich et al. (1994). Dominant $l s d 2$ and $l s d 4$ mutants were used as pollen donors in crosses to a homozygous NahG line. Successful $F_{1}$ crosses were verified by the presence of lesions. $F_{2}$ seeds from the $l s d 2 \times \mathrm{NahG} \mathrm{F}_{1}$ plants were plated on germination medium as described in Weymann et al. (1995) supplemented with $50 \mu \mathrm{g}$ of kanamycin per ml to identify $n a h G^{-}$ expressing progeny. Lesion-positive plants were transferred to soil and $\mathrm{F}_{3}$ seed was collected and used for the reported experiments. $\mathrm{F}_{2}$ seed harvested from $l s d 4 \times \mathrm{NahG} \mathrm{F}_{1}$ plants was used for all experiments.

\section{RNA isolation and analysis.}

Whole plants or leaf samples were harvested and frozen in liquid nitrogen. After plants and leaf samples were ground to powder, RNA was extracted as described by Verwoerd et al. (1989). Electrophoresis of RNA through agarose-formalde-

Isd2

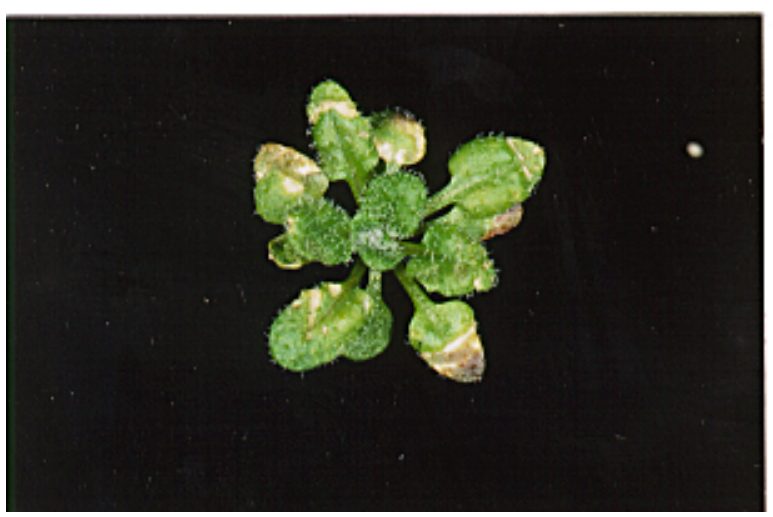

hyde gels, transfer to Gene Screen Plus nylon membranes (New England Nuclear, Boston), PR gene probes (PR-1, PR2, and PR-5 cDNAs), and washing conditions have been described (Uknes et al. 1992). The $n a h G$ gene was described in Gaffney et al. (1993) and the $\beta$-tubulin gene probe was described in Delaney et al. (1995).

\section{Histochemistry and microscopy.}

Leaf material for sectioning was fixed and sectioned as described in Dietrich et al. (1994). Leaf sections were mounted on microscope slides and de-waxed by two successive 5-min washes in xylene. Samples were rehydrated by 5 -min incubations in $100,100,75$, and $40 \%$ ethanol, and water, respectively. For callose staining, samples were treated for $5 \mathrm{~min}$ in $0.15 \mathrm{M}$ $\mathrm{K}_{2} \mathrm{HPO}_{4}$ plus $0.01 \%$ aniline blue. Samples were observed by ultraviolet epifluorescence as described in Dietrich et al. (1994).

\section{Peronospora parasitica assays.}

Peronospora parasitica isolate Noco was maintained and inoculated as described previously (Uknes et al. 1993b). $l s d 2$ $\times$ NahG progeny were 4 weeks old prior to inoculation with a suspension of $1 \times 10^{5}$ conidiospores $\mathrm{ml}^{-1}$ of water.

\section{ACKNOWLEDGMENTS}

We thank Leslie Friedrich, Kay Lawton, Klaus Maleck, Antonio Molina, Urs Neuenschwander, Henry-York Steiner, and Michael Willits for critically reading the manuscript.

\section{LITERATURE CITED}

Aist, J. R., and Israel, H. W. 1977. Papilla formation: Timing and significance during penetration of barley coleoptiles by Erysiphe graminis hordei. Phytopathology 67:455-461.

Becker, F., Buschfeld, E., Schell, J., and Bachmair, A. 1993. Altered response to viral infection by tobacco plants perturbed in ubiquitin system. Plant J. 3:875-881.

Beffa, R., Szell, M., Meuwly, P., Pay, A., Vögeli-Lange, R., Métraux, J.P., Neuhaus, G., Meins, F., and Nagy, F. 1995. Cholera toxin elevates pathogen resistance and induces pathogenesis-related gene expression in tobacco. EMBO J. 14:5753-5761.

Bowling, S. A., Guo, A., Cao, H., Gordon, A. S., Klessig, D. F., and Dong, X. 1994. A mutation in Arabidopsis that leads to constitutive expression of systemic acquired resistance. Plant Cell 6:1845-1857.

Fig. 4. Peronospora parasitica susceptibility in $l s d 2 / \mathrm{NahG}$ plants. Inoculation of $l s d 2$ progeny that either lack (left) or contain (right) $n a h G$ shows that fungal resistance in $l s d 2$ is lost by expression of salicylate hydroxylase. Photograph of plants was taken 7 days after inoculation. 
Bozarth, R. F. 1962. Some biological and physiological aspects of the systemic resistance induced by tobacco mosaic virus in hypersensitive tobacco. Ph.D. diss. Cornell University, Ithaca, NY.

Chen, Z., Malamy, J., Henning, J., Conrath, U., Sánchez-Casas, P., Silva, H., Ricigliano, J., and Klessig, D. F. 1995. Induction, modification, and transduction of the salicylic acid signal in plant defense responses. Proc. Natl. Acad. Sci. USA 92:4134-4137.

Dangl, J. L., Dietrich, R. A., and Richberg, M. H. 1996. Death don't have no mercy: Cell death programs in plant-microbe interactions. Plant Cell 8:1793-1807.

Dekayos, E. 1972. Callose formation by bruising and heating of tomatoes and its presence in processed products. J. Food Sci. 37:562-567.

Delaney, T. P., Friedrich, L., and Ryals, J. A. 1995. Arabidopsis signal transduction mutant defective in chemically and biologically induced disease resistance. Proc. Natl. Acad. Sci. USA 92:6602-6606.

Delaney, T. P., Uknes, S., Vernooij, B., Friedrich, L., Weymann, K., Negrotto, D., Gaffney, T., Gut-Rella, M., Kessmann, H., Ward, E., and Ryals, J. 1994. A central role of salicylic acid in plant disease resistance. Science 266:1247-1250.

Dietrich, R. A., Delaney, T. P., Uknes, S. J., Ward, E. R., Ryals, J. A., and Dangl, J. L. 1994. Arabidopsis mutants simulating disease resistance response. Cell 77:565-577.

Eschrich, W. 1975. Sealing systems in plants. Pages 39-56 in: Encyclopedia of Plant Physiology. S. Pirson and M. Zimmerman, eds. Springer-Verlag, New York.

Fauth, M., Merten, A., Hahn, M. G., Jeblick, W., and Kauss, H. 1996. Competence for elicitation of $\mathrm{H}_{2} \mathrm{O}_{2}$ in hypocotyls of cucumber is induced by breaching the cuticle and is enhanced by salicylic acid. Plant Physiol. 110:347-354.

Friedrich, L., Lawton, K., Ruess, W., Masner, P., Specker, N., Gut-Rella, M., Meier, B., Dincher, S., Staub, T., Uknes, S., Métraux, J.-P., Kessmann, H., and Ryals, J. 1996. A benzothiadiazole derivative induces systemic acquired resistance in tobacco. Plant J. 10:61-70.

Gaffney, T., Friedrich, L., Vernooij, B., Negrotto, D., Nye, G., Uknes, S., Ward, E., Kessmann, H., and Ryals, J. 1993. Requirement of salicylic acid for the induction of systemic acquired resistance. Science 261: 754-756.

Görg, R., Hollricher, K., and Schulze-Lefert, P. 1993. Functional analysis and RFLP-mediated mapping of the Mlg resistance locus in barley. Plant J. 3:857-866.

Görlach, J., Volrath, S., Knauf-Beiter, G., Hengy, G., Beckhove, U., Kogel, K.-H., Oostendorp, M., Staub, T., Ward, E., Kessmann, H., and Ryals, J. 1996. Benzothiadiazole, a novel class of inducers of systemic acquired resistance, activates gene expression and disease resistance in wheat. Plant Cell 8:629-643.

Greenberg, J. T., Guo, A., Klessig, D. F., and Ausubel, F. M. 1994. Programmed cell death in plants: A pathogen-triggered response activated coordinately with multiple defense functions. Cell 77:551-563.

Hunt, M. D., and Ryals, J. A. 1996. Systemic acquired resistance signal transduction. Crit. Rev. Plant Sci. 15:583-606.

Jaffe, M. J., Huberman, M., Johnson, J., and Telewski, F. W. 1985. Thigmomorphogenesis: The induction of callose formation and ethylene evolution by mechanical perturbation in bean stems. Physiol. Plant. 64:271-279.

Jones, A. M., and Dangl, J. L. 1996. Logjam at the Styx: Programmed cell death in plants. Trends Plant Sci. 1:114-119.

Keen, N. T. 1982. Specific recognition in gene-for-gene host-parasite systems. Adv. Plant Pathol. 2:35-82.

Keen, N. T., and Staskawicz, B. J. 1988. Host range determinants in plant pathogens and symbionts. Annu. Rev. Microbiol. 42:421-440.

Klement, Z. 1982. Hypersensitivity. Pages 149-177 in: Phytopathogenic Procaryotes. M. S. Mount and G. H. Lacy, eds. Academic Press, New York.

Koga, H., Mayama, S., and Shishiyama, J. 1980. Correlation between the deposition of fluorescent compounds in papillae and resistance in barley against Erysiphe graminis hordei. Can. J. Bot. 58:536-541.

Koga, H., Zeyen, R. J., Bushnell, W. R., and Ahlstrand, G. G. 1988. Hypersensitive cell death, autoflourescence, and insoluble silicon accumulation in barley leaf epidermal cells under attack by Erysiphe graminis f. sp. hordei. Physiol. Mol. Plant Pathol. 32:395-409.

Kuc, J. 1982. Induced immunity to plant disease. BioScience 32:854-860.

Langford, A. N. 1948. Autogenous necrosis in tomatoes immune from Cladosporium fulvum Cooke. Can. J. Res. 26:35-64.

Lawton, K., Friedrich, L., Hunt, M., Weymann, K., Delaney, T. P.,
Kessmann, H., Staub, T., and Ryals, J. 1996. Benzothiadiazole induces disease resistance in Arabidopsis by activation of the systemic acquired resistance signal transduction pathway. Plant J. 10:71-82.

Lawton, K., Weymann, K., Friedrich, L., Vernooij, B., Uknes, S., and Ryals, J. 1995. Systemic acquired resistance in Arabidopsis requires salicylic acid but not ethylene. Mol. Plant-Microbe Interact. 8:863-870.

Mauch-Mani, B., and Slusarenko, A. J. 1994. Systemic acquired resistance in Arabidopsis thaliana induced by a predisposing infection with a pathogenic isolate of Fusarium oxysporum. Mol. PlantMicrobe Interact. 7:378-383.

Mayama, S., and Shishiyama 1976. Localized accumulation of fluorescent and u.v.-absorbing compounds at penetration sites in barley leaves infected with Erysiphe graminis hordei. Physiol. Plant Pathol. 13:347-354.

Mittler, R., Shulaev, V., and Lam, E. 1995. Coordinated activation of programmed cell death and defense mechanisms in transgenic tobacco plants expressing a bacterial proton pump. Plant Cell 7:29-42.

Mur, L. A. J., Naylor, G., Warner, S. A. J., Sugars, J. M., White, R. F., and Draper, J. 1996. Salicylic acid potentiates defence gene expression in tissue exhibiting acquired resistance to pathogen attack. Plant J. 9:559-571.

Neuenschwander, U., Lawton, K., and Ryals, J. 1996. Systemic acquired resistance. Pages 81-106 in: Plant Microbe Interactions. G. Stacey and N. T. Keen, eds. Chapman \& Hall, New York.

Prokipcak, B., and Ormrod, D. P. 1986. Visible injury and growth responses of tomato and soybean to combinations of nickel, copper and ozone. Water Air Soil Pollut. 27:329-340.

Ross, A. F. 1961. Systemic acquired resistance induced by localized virus infections in plants. Virology 14:340-358.

Ryals, J., Lawton, K. A., Delaney, T. P., Friedrich, L., Kessmann, H., Neuenschwander, U., Uknes, S., Vernooij, B., and Weymann, K. 1995. Signal transduction in systemic acquired resistance. Proc. Natl. Acad. Sci. USA 92:4202-4205.

Ryals, J., Uknes, S., and Ward, E. 1994. Systemic acquired resistance. Plant Physiol. 104:1109-1112.

Ryals, J. A., Neuenschander, U. H., Willits, M. G., Molina, A., Steiner, H.-Y., and Hunt, M. D. 1996. Systemic acquired resistance. Plant Cell 8:1809-1819.

Shirasu, K., Dixon, R. A., and Lamb, C. 1996. Signal transduction in plant immunity. Curr. Opin. Immunol. 8:3-7.

Tighe, D., and Heath, M. 1982. Callose induction in cowpea by uridine diphosphate glucose and calcium phosphate-boric acid treatments. Plant Physiol. 69:366-370.

Uknes, S., Dincher, S., Friedrich, L., Negrotto, D., Williams, S., Taylor, H., Potter, S., Ward, E., and Ryals, J. 1993a. Regulation of pathogenesisrelated protein-1a gene expression in tobacco. Plant Cell 5:159-169.

Uknes, S., Mauch-Mani, B., Moyer, M., Williams, S., Dincher, S., Chandler, D., Potter, S., Slusarenko, A., Ward, E., and Ryals, J. 1992. Acquired resistance in Arabidopsis. Plant Cell 4:645-656.

Uknes, S., Winter, A. M., Delaney, T., Vernooij, B., Morse, A., Friedrich, L., Nye, G., Potter, S., Ward, E., and Ryals, J. 1993b. Biological induction of systemic acquired resistance in Arabidopsis. Mol. PlantMicrobe Interact. 6:692-698.

Vernooij, B., Friedrich, L., Ahl Goy, P., Staub, T., Kessmann, H., and Ryals, J. 1995. 2,6-Dichloroisonicotinic acid-induced resistance to pathogens without the accumulation of salicylic acid. Mol. PlantMicrobe Interact. 8:228-234.

Verwoerd, B., Dekker, M., and Hoekema, A. 1989. A small-scale procedure for the rapid isolation of plant RNAs. Nucleic Acids Res. 17: 2362 .

Walbot, V., Hoisington, D. A., and Neuffer, M. G. 1983. Disease lesion mimic mutations. Pages 431-442 in: Genetic Engineering of Plants. T. Kosuge, C. P. Meredith, and A. Hollaender. Plenum Publishing, New York.

Weymann, K., Hunt, M., Uknes, S., Neuenschwander, U., Lawton, K., Steiner, H.-Y., and Ryals, J. 1995. Suppression and restoration of lesion formation in Arabidopsis lsd mutants. Plant Cell 7:2013-2022.

Wolter, M., Hollricher, K., Salamini, F., and Schulze-Lefert, P. 1993. The mlo resistance alleles to powdery mildew infection in barley trigger a developmentally controlled defence mimic phenotype. Mol. Gen. Genet. 239:122-128.

Xu, Y., Chang, L. P., Liu, D., Narasimhan, L., Raghothama, K., Hasegawa, P., and Bressan, R. 1994. Plant defense genes are synergistically induced by ethylene and methyl jasmonate. Plant Cell 6:1077-1085. 